\title{
PENDAMPINGAN PEREMPUAN KORBAN TINDAK KEKERASAN OLEH PUSAT PELAYANAN TERPADU PEMBERDAYAAN PEREMPUAN DAN ANAK (P2TP2A)
}

\author{
Rr. Niken Sitoresmi*) dan Siti Amanah \\ Departemen Sains Komunikasi dan Pengembangan Masyarakat, Fakultas Ekologis Manusia, IPB \\ *)Email: nikensitoresmi90@gmail.com
}

\begin{abstract}
Gender as a social construction and beliefs that thrive in the community produce gender inequalities experienced by women. This makes the weak position of women so prone to cases and acts of violence. Comprehensive facilitation for victims of violence are indispensable so that there should be an institution that takes care of this. Therefore, this study was done to find out, identify, describe and analyze the facilitation of women victims of violence by the integrated services centre empowerment of women and children (P2TP2A) DKI Jakarta. The research used survey using questionnaires, instruments was designed following concepts on gender ideology and the role of facilitation from P2TP2A DKI Jakarta. Quantitative and qualitative analysis were used to explain research results. Gender ideology attached to the respondents pointed out that the majority of the respondents have a positive gender ideology that leads to equity and equality of gender. The majority of respondents have knowledge about violence are high by agreeing to things that are associated with violence. There is no signification between the ideology gender of women victims with violence experienced. On the other hand, there is a signification between knowledge about violence of women victims with violence experienced. Respondents perceive that facilitation from P2TP2A DKI Jakarta is effective according to the needs of the victims. The activities conducted by $P 2 T P 2 A$ help assisted process of recovery and motivate the women to have specific life skills, such as household economics.
\end{abstract}

Keywords: violence, recovery, empowerment, women victims, P2TP2A.

\section{PENDAHULUAN}

\section{Latar Belakang}

Tujuan Pembangunan Milenium sampai dengan tahun 2015, salah satu butirnya adalah meningkatnya kualitas hidup perempuan, mengurangi adanya diskriminasi. kesenjangan dan tidak adanya diskriminasi. Kemajuan pembangunan kualitas hidup manusia Indonesia tercermin dari Indeks Pembangunan Manusia (IPM). Indeks pembangunan manusia Indonesia dari tahun ke tahun mengalami peningkatan. Badan Pusat Statistik memaparkan angka IPM atau Human Development Indeks (HDI) Indonesia dari tahun 2006 sampai dengan tahun 2010 berturut-turut yaitu 70.10 $70.5971 .17 \quad 71.76 \quad 72.27$. Untuk angka Indeks Pembangunan Gender (IPG) (Gender-related Development Index/GDI) sendiri dari tahun 2006 sampai dengan tahun 2008 menurut Kementrian Pemberdayaan Perempuan dan Perlindungan Anak bekerjasama dengan Badan Pusat Statistik, yaitu 65,1 65,3, 66,38. Sedangkan angka Gender Empowerment Measurement (GEM) atau Indeks Pemberdayaan Gender (IDG) dari tahun 2006 sampai tahun 2008, yaitu 61,3, 61,8, 62,27. Kesenjangan antara angka HDI dengan angka GDI menunjukkan bahwa keberhasilan pembangunan sumber daya manusia walaupun terjadi peningkatan dari tahun ke tahun secara keseluruhan, namun belum sepenuhnya diikuti dengan keberhasilan pembangunan gender atau masih terdapat kesenjangan gender. Angka GEM Indonesia relatif rendah, hal ini menunjukkan partisipasi dan kesempatan perempuan masih rendah di bidang politik, ekonomi, dan pengambilan keputusan.

Kebijakan pembangunan yang mendukung kesetaraan dan keadilan gender menjadi salah satu instrumen penting dalam penyelenggaraan pemerintahan. Untuk mencapai hal tersebut diterbitkan Instruksi Presiden Nomor 9 Tahun 2000 tentang Pengarusutamaan Gender dalam Pembangunan Nasional. Pemerintah melalui Kementerian Negara Pemberdayaan Perempuan (KNPP) telah membuat komitmen politik bahwa perempuan dan anak merupakan sasaran pembangunan di semua bidang dan program pembangunan. Semangat ini juga mendorong masyarakat terlibat dalam program- 
program pembangunan dalam pemberdayaan dan perlindungan perempuan dari segala bentuk tindak ketidakadilan gender, salah satunya adalah kekerasan. Oleh karena itu, Kementerian Pemberdayaan Perempuan dan Perlindungan Anak memfasilitasi pembentukan Pusat Pelayanan Terpadu Pemberdayaan Perempuan dan Anak (P2TP2A). Salah satunya adalah P2TP2A Provinsi DKI Jakarta yang menyediakan pelayanan bagi perempuan dan anak korban kekerasan di DKI Jakarta yang meliputi: pelayanan informasi, psikologis dan hukum, pendampingan dan advokasi, serta pelayanan medis dan rumah aman (shelter) melalui rujukan secara gratis. Adanya P2TP2A di DKI Jakarta diharapkan dapat membuat terjalinnya hubungan kerjasama antara masyarakat dan pemerintah dalam upaya pemenuhan hakhak perempuan dan anak yang menjadi korban kekerasan di DKI Jakarta.

\section{Masalah Penelitian}

Wilayah DKI Jakarta memiliki jumlah penduduk yang terdaftar pada tahun 2011 sebesar 9,73 juta jiwa dengan rasio jenis kelamin 103 dan laju pertumbuhan penduduk 1,27 persen per tahun (statistik daerah Provinsi DKI Jakarta 2011). Kondisi pertumbuhan kota Jakarta tersebut sudah semakin tinggi. Dampak tingginya pertumbuhan di Jakarta yaitu menimbulkan banyak permasalahan dari mulai masalah ekonomi, kemiskinan hingga masalah-masalah sosial di DKI Jakarta salah satunya yaitu ancaman kekerasan terhadap perempuan. Untuk itu diperlukan penanganan yang komprehensif terhadap korban kekerasan di DKI Jakarta sehingga perlu ada lembaga yang berfokus menangani hal ini. Adanya P2TP2A di DKI Jakarta diharapkan dapat membuat terjalinnya hubungan kerjasama antara masyarakat dan pemerintah dalam upaya pemenuhan hak-hak perempuan dan anak yang menjadi korban kekerasan di DKI Jakarta. Hal tersebut kemudian memunculkan keingintahuan penulis mengenai:

1. Apa sajakah jenis kekerasan yang dialami perempuan dampingan P2TP2A DKI Jakarta?

2. Bagaimana hubungan antara ideologi gender dan pengetahuan tentang kekerasan dengan kekerasan yang dialami perempuan dampingan P2TP2A DKI Jakarta?

3. Bagaimana strategi pendampingan P2TP2A DKI Jakarta dan kemampuan/daya pulih perempuan korban tindak kekerasan dampingan P2TP2A?

\section{Tujuan Penelitian}

Adapun tujuan penelitian ini adalah:

1. Mendeskripsikan jenis kekerasan yang dialami perempuan dampingan P2TP2A DKI Jakarta.

2. Menganalisis hubungan antara ideologi gender dan pengetahuan tentang kekerasan dengan kekerasan yang dialami perempuan dampingan P2TP2A DKI Jakarta.

3. Mendeskripsikan strategi pendampingan P2TP2A DKI Jakarta dan kemampuan/daya pulih perempuan korban tindak kekerasan dampingan P2TP2A.

\section{PENDEKATAN TEORITIS}

\section{Tinjauan Pustaka}

\section{Konsep, Ideologi dan Peran Gender}

Istilah gender menurut Haralambos dan Holborn dalam Sunarto (2009) mempunyai konotasi psikologis, sosial, dan kultural antara pria dan wanita dalam menjalankan peran-peran maskulinitas dan feminitas tertentu di masyarakat. Seperti dikutip dalam Agusni S (2010) konsep gender dapat digunakan untuk melakukan analisis agar lebih dicermati pada aspek produktif, reproduktif, sosial, dan kontrol atau penguasaan.

Saptari (1997) mengemukakan mengenai konsep ideologi gender bahwa ideologi gender merupakan segala aturan, nilai, stereotipe yang mengatur hubungan antara perempuan dan laki-laki terlebih dulu melalui pembentukan identitas feminin dan maskulin. Ideologi ini bisa terbentuk di berbagai tingkat, misalnya, tingkat negara, komunitas, atau keluarga dan disosialisasikan melalui berbagai pranata sosial yang dikuasai dan dikendalikan oleh kelompok-kelompok yang berkuasa dalam masyarakat.

Peran menurut Hubeis (2010) adalah aspek dinamis dari status seseorang yang sudah terpola dan berada di sekitar hak dan kewajiban tertentu yang dipengaruhi oleh seperangkat harapan orang lain terhadap perilaku yang seharusnya ditampilkan oleh orang yang bersangkutan. Peran gender berubah dari waktu ke waktu karena adanya perkembangan yang mempengaruhi nilainilai dan norma-norma di masyarakat. Dengan demikian, peran gender menampilkan kesepakatan pandangan dalam masyarakat dan budaya tertentu perihal ketepatan dan kelaziman bertindak untuk seks tertentu (jenis kelamin tertentu) dan masyarakat tertentu. Peran gender berbeda antar-masyarakat atau bahkan antar kelompok di dalam masyarakat tertentu. Pemahaman tentang subyek-obyek, dominan-tidak dominan, superior-imperior serta pembagian peran-peran yang tidak seimbang antara anggota keluarga laki-laki (ayah, anak laki-laki) dan perempuan (ibu, anak perempuan) seringkali memposisikan laki-laki lebih mendapatkan hak-hak istimewa, sedangkan perempuan sebagai kaum kelas kedua.

Menurut Hubeis (2010), secara universal peran gender untuk perempuan dan laki-laki diklasifikasikan dalam tiga peran pokok yaitu;

1. Peran reproduktif (domestik) adalah peran yang dilakukan oleh seseorang untuk melakukan kegiatan yang terkait dengan pemeliharaan sumberdaya manusia dan tugas-tugas kerumahtanggaan seperti,

2. Peran produktif (publik) adalah peran yang dilakukan oleh seseorang, menyangkut pekerjaan menghasilkan barang dan jasa untuk dikonsumsi dan diperdagangkan (petani, nelayan, pedagang, dll).

3. Peran masyarakat (sosial) adalah peran yang dilakukan oleh seseorang untuk berpartisipasi di dalam kegiatan sosial kemasyarakatan yang terkait dengan kegiatan jasa dan partisipasi politik. 


\section{Isu Gender dalam Pembangunan}

Menurut Hubeis 2010 analisis peran gender merupakan kajian sistematik tentang peranan, hubungan dan proses yang difokuskan pada ketidaksetaraan dalam akses dan kontrol terhadap kekuasaan, kekayaan, dan beban kerja antara perempuan dan laki-laki dalam keseluruhan tatanan kehidupan masyarakat. Ketidaksetaraan tersebut dapat dilihat dari persentase perbandingan angka melek huruf penduduk berusia 15 tahun ke atas di Indonesia tahun 2009 menurut Badan Pusat Statistik (2010), yaitu: laki-laki 95,65 persen, sedangkan perempuan 89,68 persen. Kesenjangan gender juga terjadi di bidang ketenagakerjaan. Hal tersebut dapat dilihat dari rasio antara angkatan kerja dengan jumlah penduduk usia kerja yang dikenal dengan istilah Tingkat Partisipasi Angkatan Kerja (TPAK). TPAK pada Februari 2011 menunjukkan bahwa laki-laki mempunyai TPAK yang lebih besar daripada perempuan yaitu 72,26 dibandingkan 47,14 (BPS 2011).

Selanjutnya, persoalan lain adalah banyaknya hukum dan peraturan perundang-undangan yang bias gender dan diskriminatif terhadap perempuan. Perangkat hukum pidana yang ada belum cukup lengkap dalam melindungi setiap individu, salah satu diantaranya adalah perlindungan terhadap perempuan korban kekerasan. Menurut data dan dokumentasi dari Komnas Perempuan jumlah kekerasan terhadap perempuan (KTP) yang tercatat ditangani lembaga pengada layanan meningkat setiap tahun (tahun 2001-2008). Menurut Komnas Perempuan 2009, pada tahun 2008 peningkatan jumlah KTP mencapai lebih dari dua kali lipat dibandingkan tahun 2007 (25.522 kasus KTP), yaitu 213 persen mencapai sejumlah 54.425 kasus KTP. Pada tahun 2009, peningkatan jumlah KTP mencapai 143.586 kasus atau naik 263 persen dari jumlah KTP tahun 2008 (Komnas perempuan 2010). Sedangkan untuk tahun 2010 menurut Komnas perempuan 2011, jumlah perempuan korban kekerasan sebanyak 105.103 orang. Kesenjangan gender sebagaimana diuraikan di atas, tentu merugikan perempuan. Oleh karena itu, upaya pemberdayaan perempuan mutlak diperlukan untuk meningkatkan status dan kedudukan perempuan di berbagai bidang pembangunan.

\section{Perempuan dan Kekerasan}

Isu gender dalam pembangunan yang telah dibahas pada sub bab sebelumnya tidak lepas dari hasil konstruksi sosial-budaya di masyarakat yang menomorduakan perempuan. Budaya ini terkonstruksi secara terusmenerus dalam waktu yang lama sehingga melahirkan pola hubungan yang tidak seimbang antara perempuan dan laki-laki. Ketidakseimbangan ini melahirkan dampak negatif yang menyebabkan lemahnya posisi perempuan sehingga rentan terhadap kekerasan. Pernyataan tersebut diperkuat oleh Widanti (2005), bahwa ketidakadilan dan ketidaksamaan dalam pengertian kesehatan perempuan, beban kerja, akses terhadap pekerjaan dan pendapatan, serta kekerasan yang dialami perempuan sebenarnya bersumber dari pelabelan negatif terhadap perempuan.

Kekerasan menurut Kartika (2010) merupakan setiap perbuatan melawan hukum dengan atau tanpa menggunakan sarana terhadap fisik dan psikis yang menimbulkan bahaya bagi nyawa, badan atau menimbulkan terampasnya kemerdekaan seseorang. Sedangkan kekerasan terhadap perempuan merupakan setiap tindakan berdasarkan perbedaan jenis kelamin yang berakibat kesengsaraan atau penderitaan perempuan secara fisik, seksual atau psikologis, termasuk ancaman tindakan tertentu, pemaksaan atau perampasan kemerdekaan secara sewenang-wenang, baik yang terjadi di ranah publik atau dalam kehidupan pribadi.

Menurut Sunarto (2009), kekerasan terhadap perempuan mempunyai dua bentuk yaitu, kekerasan di rumah dan kekerasan di lingkungan sosialnya. Kekerasan di rumah biasanya terjadi dalam bentuk kekerasan fisik oleh suami terhadap istrinya. Kekerasan di lingkungan sosial terjadi dalam bentuk perlakuan diskriminatif terhadap kaum wanita untuk menjalankan fungsi-fungsi sosialnya. Kekerasan senantiasa melibatkan dua pihak, pelaku (subyek), dan korban (obyek). Apabila subyek kekerasan itu dilakukan oleh seorang individu secara langsung disebut sebagai kekerasan personal, akan tetapi apabila pelakunya tidak tampak maka disebut sebagai kekerasan struktural. Pemukulan, penganiayaan, oleh satu orang terhadap orang lainnya merupakan tindak kekerasan personal. Sedangkan kekerasan struktural mewujud dalam bentuk eksploitasi, ketidakadilan sosial, kemiskinan struktural, ketidakseimbangan ekologis, ancaman dan ketakutan. Diantara berbagi faktor yang mendorong terjadinya tindak kekerasan itu, faktor kekuasaan (power) merupakan sebab yang menonjol dalam mendorong terjadinya tindak kekerasan, baik secara personal ataupun struktural. Selama pandangan yang berorientasi kekuasaan ini hadir, selama itu pula kaum wanita akan selalu mengalami kekerasan gender.

\section{Kerangka Pemikiran}

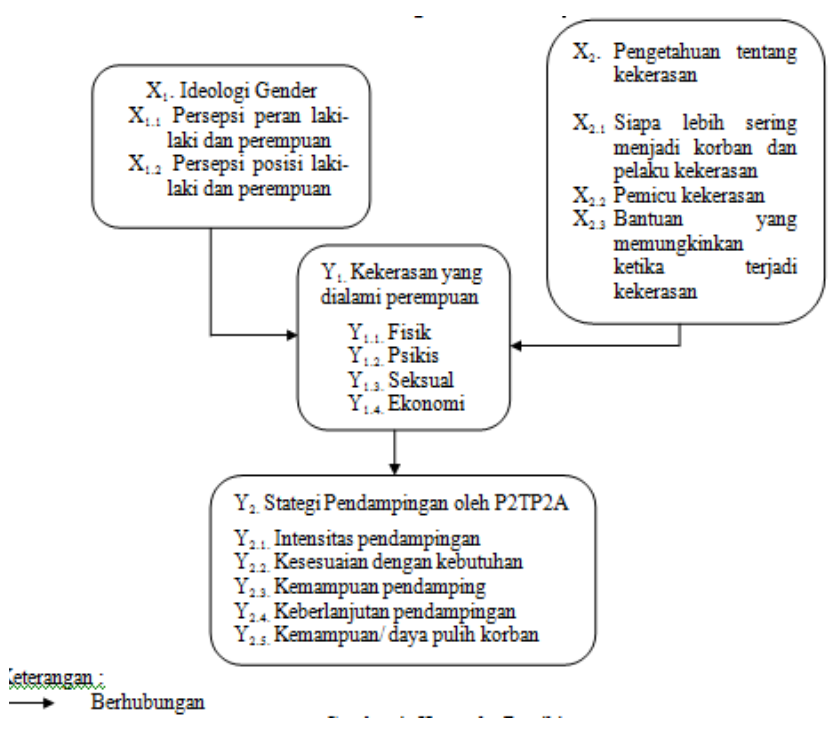

Gambar 1. Kerangka pemikiran

\section{METODOLOGI PENELITIAN}

Penelitian ini dilakukan dengan pendekatan kuantitatif yang menggunakan metode penelitian survei. Survei adalah penelitian dengan mengumpulkan informasi 
dari suatu sampel dengan menanyakan melalui angket atau interview supaya menggambarkan berbagai aspek dari populasi Koentjaraningrat (1994). Data primer yang berupa data kuantitatif diperoleh dari pengumpulan data melalui instrumen utama penelitian survei, yaitu kuesioner. Kuesioner tersebut yang diajukan kepada responden berisi isian untuk data pribadi termasuk kekerasan yang pernah dialami, 15 pernyataan ideologi gender, 25 pernyataan untuk pengetahuan tentang kekerasan, 10 pernyataan mengenai strategi pendampingan P2TP2A yang semuanya berskala Likert dan tabel untuk evaluasi kegiatan edukasi yang pernah dirasakan termasuk kemampuan pendamping. Kuesioner ini bermanfaat untuk memperoleh informasi secara tertulis dari responden berkaitan dengan pertanyaan yang diajukan untuk menjawab masalah penelitian.

Penelitian ini didukung pula oleh pendekatan kualitatif. Pendekatan kualitatif merupakan prosedur penelitian yang mementingkan diperolehnya informasi atau data dari subyek penelitian secara alamiah, berdasarkan pengalaman sosial mereka masing-masing dan data yang didapatkan merupakan data deskriptif yang berupa kata-kata dari subyek penelitian. Dalam pendekatan kualitatif, penelitian ini menggunakan wawancara mendalam yang dilakukan pada responden dan informan untuk melengkapi kebutuhan data primer penelitian. Data kualitatif diperoleh dari pengumpulan data melalui wawancara mendalam agar dapat menangkap pengalaman, persepsi, pemikiran, perasaan, dan pengetahuan dari subyek penelitian. Data sekunder diperoleh melalui literatur, catatan, data dan dokumentasi dari P2TP2A.

\section{PEMBAHASAN}

\section{Profil Pusat Pelayanan Terpadu Pemberdayaan Perempuan dan Anak Provinsi DKI Jakarta}

\section{Sejarah berdirinya P2TP2A DKI Jakarta}

Pada tahun 2002 Kementerian Negara Pemberdayaan Perempuan mendorong pembentukan P2TP2A di seluruh Indonesia untuk membantu penanganan perempuan dan anak korban kekerasan yang masih dirasakan kurang mendapat perhatian dan sampai saat ini pembentukan P2TP2A sudah terdapat di 17 provinsi dan $113 \mathrm{Kabupaten/kota.}$

Pada tahun 2002 yang sama, bidang pemberdayaan perempuan Provinsi DKI Jakarta membuat kajian kerentanan perempuan dan anak korban kekerasan dan menemukan temuan bahwa perempuan dan anak di DKI Jakarta rentan terhadap kekerasan. Pada tahun 2003-2004 dilakukan kajian dan studi banding perlunya P2TP2A dan hasil studi menyatakan bahwa perlu dibentuknya P2TP2A di Provinsi DKI Jakarta. Pemerintah Provinsi DKI Jakarta mencanangkan pembentukan P2TP2A tanggal 22 Juni 2004 saat peringatan HUT DKI ke-478.

Pusat Pelayanan Terpadu Pemberdayaan Perempuan dan Anak (P2TP2A) yang beralamat di J1. Bekasi Timur Raya Km. 18 Pulo Gadung, Jakarta Timur, Telp 021- 47882898, Fax 021-47882899 adalah pusat pelayanan terpadu yang menyediakan pelayanan bagi perempuan dan anak korban kekerasan di DKI Jakarta.
Layanan yang diberikan di P2TP2A DKI Jakarta, meliputi: pelayanan informasi, konsultasi psikologis dan hukum, pendampingan dan advokasi, serta pelayanan medis dan rumah aman (shelter) melalui rujukan secara gratis.

\section{Gambaran Statistik Populasi Dampingan P2TP2A DKI Jakarta}

P2TP2A DKI Jakarta bersama mitra kerja terkait pada tahun 2006 hingga 2010 telah menangani sekitar 5931 klien kasus kekerasan. Untuk tahun 2006 sendiri sekitar 1015 klien, tahun 2007 sebanyak 1583 klien, tahun 2008 sebanyak 1448 klien, tahun 2009 sebanyak 950 klien serta untuk tahun 2010 sebanyak 935 klien.

Klien P2TP2A Provinsi DKI Jakarta terdiri dari perempuan dan anak yang mengalami tindak kekerasan. Selama tahun 2006-2010 klien perempuan P2TP2A sebanyak 72 persen, sedangkan untuk klien anak sebanyak 28 persen dari keseluruhan klien yang telah ditangani oleh P2TP2A. Ada berbagai jenis kasus kekerasan yang telah ditangani oleh P2TP2A, diantaranya kasus KDRT yang terbesar yakni sekitar 68 persen, kasus kekerasan seksual 18 persen, kasus perdagangan perempuan sebanyak 1 persen dan jenis kekerasan diluar dari ketiga kasus sebelumya sebesar 13 persen dari keseluruhan jumlah jenis kasus kekerasan yang telah ditangani oleh P2TP2A.

Dari beberapa jenis kasus kekerasan yang telah ditangani oleh P2TP2A dapat diketahui bahwa jenis kekerasan yang terbesar adalah KDRT, yaitu sebesar 68 persen. KDRT sendiri ada berbagai macam bentuknya, diantara adalah kekerasan fisik, psikis, seksual, dan penelantaran. P2TP2A dari tahun 2006-2010 telah menangani bentuk KDRT untuk kekerasan fisik sebesar 66 persen, kekerasan psikis 18 persen, kekerasan seksual 6 persen, serta bentuk kekerasan penelantaran sebesar 10 persen

Data statistik dari P2TP2A DKI Jakarta tahun 2010 dapat diketahui besarnya persentase kasus kekerasan yang terjadi di lima bagian wilayah di DKI Jakarta. Kasus kekerasan tertinggi terjadi di wilayah Jakarta Timur dengan persentase 32 persen, kemudian diikuti oleh wilayah Jakarta bagian Barat dengan persentase kasus kekerasan sebesar 16 persen. Faktor yang dapat mempengaruhi tingginya persentase kasus kekerasan di Jakarta Timur salah satunya adalah keberadaan terminal bus (Pulo Gadung) yang merupakan tempat umum dan rawan terhadap tindak kekerasan. Selain itu juga karena keberadaan P2TP2A itu sendiri yang terletak di wilayah Jakarta Timur sehingga mampu memaksimalkan fungsinya untuk menangani perempuan dan anak korban kekerasan di wilayah tersebut. Persentase kasus kekerasan terbesar ketiga dimiliki oleh wilayah Jakarta Utara serta kasus pada Polda Metro Jaya dengan besar persentase yang sama yaitu 15 persen. Terakhir kasus kekerasan yang dapat dikategorikan terendah dengan persentase 11 persen adalah wilayah Jakarta Selatan dan Jakarta Pusat. 


\section{Karakteristik Responden (Perempuan Dampingan P2tp2a Provinsi Dki Jakarta)}

\section{Karakteristik Individu Responden}

P2TP2A DKI Jakarta dari data pada tahun 2011 telah mendampingi 1381 korban kekerasan dengan persentase klien anak sebesar 30 persen dan klien perempuan sebesar 70 persen. Dari sejumlah angka tersebut dipilih sebanyak 30 orang responden penelitian yang sesuai kriteria. Dari sejumlah aspek yang ditanyakan, perlu diketahui karakteristik individu perempuan korban kekerasan dampingan P2TP2A. Karakteristik yang akan diuraikan meliputi, usia, pendidikan terakhir, dan status pernikahan responden yang disajikan pada Tabel 1. Dengan mengetahui karakteristik individu, dapat mempermudah lembaga menerapkan fungsi tugas dan tanggung jawabnya dalam rangka memulihkan kondisi psikologis korban kekerasan.

Berdasarkan hasil penelitian yang disajikan pada Tabel 1, dapat diketahui bahwa persentase terbesar usia responden terdapat pada usia madya yang berada pada selang antara 30-55 tahun, yakni sebesar 73 persen, sedangkan untuk kategori usia muda dan usia tua masingmasing sebesar 17 persen dan 10 persen dari keseluruhan responden.

Tabel 1. Jumlah dan Persentase Responden Berdasarkan Karakteristik Individu

\begin{tabular}{|c|c|c|c|}
\hline \multirow{2}{*}{$\begin{array}{l}\text { Karakteristik } \\
\text { Responden }\end{array}$} & \multirow{2}{*}{$\begin{array}{l}\text { Kategorisasi Sub- } \\
\text { peubah }\end{array}$} & \multicolumn{2}{|c|}{ Jumlah } \\
\hline & & $\mathrm{n}$ & $\%$ \\
\hline \multirow{4}{*}{ Usia (tahun) } & $\begin{array}{l}\text { Usia Muda } \quad(<30 \\
\text { tahun) }\end{array}$ & 5 & 17 \\
\hline & $\begin{array}{l}\text { Usia Madya (30-55 } \\
\text { tahun) }\end{array}$ & 22 & 73 \\
\hline & $\begin{array}{lll}\text { Usia } & \text { Tua } \quad(>55 \\
\text { tahun }) & & \\
\end{array}$ & 3 & 10 \\
\hline & Jumlah (N) & 30 & 100 \\
\hline \multirow{4}{*}{$\begin{array}{c}\text { Tingkat } \\
\text { Pendidikan }\end{array}$} & $\begin{array}{l}\text { Tidak sekolah }(<6 \\
\text { tahun) }\end{array}$ & 3 & 10 \\
\hline & $\begin{array}{l}\text { Lulus SD-SMP (6- } \\
9 \text { tahun) }\end{array}$ & 13 & 43 \\
\hline & $\begin{array}{l}\text { Lulus SMA (>9 } \\
\text { tahun) }\end{array}$ & 14 & 47 \\
\hline & Jumlah (N) & 30 & 100 \\
\hline \multirow{5}{*}{ Status Pernikahan } & Belum Menikah & 1 & 3 \\
\hline & Menikah & 8 & 27 \\
\hline & Cerai & 20 & 67 \\
\hline & $\begin{array}{l}\text { Menunggu Putusan } \\
\text { Pengadilan }\end{array}$ & 1 & 3 \\
\hline & Jumlah (N) & 30 & 100 \\
\hline
\end{tabular}

Berdasarkan Tabel 1 dapat diketahui bahwa mayoritas responden lulus SMA dengan jumlah persentase sebesar 47 persen. Sedangkan responden yang berpendidikan rendah karena tidak mencapai 6 tahun pendidikan formal atau hanya setingkat lulus SMP masing-masing mendapatkan pesentase sebesar 10 persen dan 43 persen dari keseluruhan persentase jumlah responden. Tingginya angka pendidikan responden dapat dipengaruhi oleh keberadaan responden yang pada umumnya berasal dan tinggal di wilayah DKI Jakarta.
DKI Jakarta merupakan Ibukota negara yang memberikan kemudahan lebih untuk akses pendidikan dan dengan lingkungan sosial-budaya yang lebih mengerti akan pentingnya pendidikan dibandingkan dengan daerahdaerah lain di Indonesia.

Hasil penelitian menunjukkan bahwa mayoritas atau sebesar 67 persen responden telah bercerai. Hal tersebut sejalan dengan tingginya tingkat pendidikan dan ideologi gender (Tabel 3) kuat yang melekat pada mayoritas responden sehingga membuat mereka sadar akan hak-hak sebagai perempuan dan seorang istri. Oleh karena itu, mayoritas responden berani untuk menuntut hak-hak mereka terhadap kekerasan (mayoritas KDRT) yang mereka alami. Pada akhirnya tuntutan tersebut berakhir pada putusan untuk mengakhiri sebuah pernikahan (bercerai). Sebesar 27 persen responden masih berstatus menikah, sisanya sebesar 3 persen responden berstatus belum menikah dan masih menggantung (sedang menunggu putusan pengadilan).

\section{Karakteristik Pelaku Kekerasan}

Menurut Sunarto 2009 kekerasan senantiasa melibatkan dua pihak, pelaku (subyek), dan korban (obyek). Pada bagian ini akan mendeskripsikan secara singkat mengenai karakteristik pelaku (subyek) kekerasan. Dalam penelitian ini, karakteristik pelaku kekerasan tidak dapat dideskripsikan secara mendalam, hanya sebatas pada usia pelaku dan hubungannya dengan responden. Hal tersebut disebabkan pertanyaan menyangkut pelaku kekerasan akan sangat sensitif dan dirahasiakan identitasnya oleh responden karena akan mengingatkan mereka tentang pengalaman pahit yang pernah mereka alami.

Tabel 2. Jumlah dan Persentase Pelaku Kekerasan Berdasarkan Karakteristik Individu dan Hubungannya dengan Responden

\begin{tabular}{|c|c|c|c|}
\hline \multirow{2}{*}{$\begin{array}{r}\text { Karakteristik } \\
\text { Pelaku }\end{array}$} & \multirow{2}{*}{$\begin{array}{l}\text { Kategorisasi Sub- } \\
\text { peubah }\end{array}$} & \multicolumn{2}{|c|}{ Jumlah } \\
\hline & & $\mathrm{n}$ & $\%$ \\
\hline \multirow{4}{*}{ Usia (tahun) } & $\begin{array}{cc}\text { Usia } & \begin{array}{c}\text { Muda }(<30 \\
\text { tahun })\end{array}\end{array}$ & 4 & 13 \\
\hline & $\begin{array}{c}\text { Usia Madya (30-55 } \\
\text { tahun) }\end{array}$ & 20 & 67 \\
\hline & $\begin{array}{c}\text { Usia Tua }(>55 \\
\text { tahun })\end{array}$ & 6 & 20 \\
\hline & Jumlah (N) & 30 & 100 \\
\hline \multirow{4}{*}{$\begin{array}{c}\text { Hubungan Pelaku } \\
\text { dengan } \\
\text { Respond } \\
\text { en }\end{array}$} & Orang Tua & 0 & 0 \\
\hline & Suami & 26 & 87 \\
\hline & $\begin{array}{c}\text { Orang lain (pacar, } \\
\text { atasan } \\
\text { kerja, dll) }\end{array}$ & 4 & 13 \\
\hline & Jumlah $(\mathrm{N})$ & 30 & 100 \\
\hline
\end{tabular}

Tabel 2 di atas, dapat dideskripsikan bahwa pelaku kekerasan mayoritas atau sebesar 67 persen berusia 30-55 tahun. Sedangkan sisanya sebanyak 13 persen dan 20 persen berusia kurang dari 30 tahun dan lebih dari 55 tahun. Jelas terlihat kesamaan mayoritas usia antara responden dan pelaku. Jika dilihat lebih lanjut pada Tabel 2 pelaku kekerasan ternyata merupakan orang terdekat responden. Terlihat bahwa sebesar 87 persen pelaku kekerasan adalah suami responden sendiri. 


\section{Ideologi Gender yang Melekat pada Responden}

Hasil penelitian pada bagian ini, menunjukkan adanya ideologi sadar gender yang dipengaruhi faktor limitasi penelitian yang tidak dapat melihat ideologi gender dari sisi pelaku dan lingkungan sekitar responden. Dari Tabel 3 diatas dapat dideskripsikan bahwa mayoritas pernyataan yang diberikan tidak disepakati oleh mayoritas responden karena dianggap terlalu memihak pada salah satu jenis kelamin. Hanya beberapa pernyataan tertentu saja yang disetujui oleh mayoritas responden, diantaranya mengenai perempuan adalah pekerja rumahan dan lakilaki pencari nafkah disetujui oleh sebesar 73 persen, kemudian sebanyak 60 persen responden menyetujui bahwa pekerjaan perempuan ialah di dalam rumah mengurus keluarga dan anak, pekerjaan laki-laki di luar rumah mencari nafkah.

Tabel 3. Jumlah dan Persentase Pandangan Responden Mengenai Peran dan Posisi Laki-laki dan Perempuan

\begin{tabular}{|c|c|c|c|}
\hline \multirow{2}{*}{ Pernyataan } & \multirow{2}{*}{$\begin{array}{l}\text { Kategorisasi } \\
\text { Sub-peubah }\end{array}$} & \multicolumn{2}{|c|}{ Jumlah } \\
\hline & & $\mathrm{n}$ & $\%$ \\
\hline $\begin{array}{l}\text { Perempuan tidak boleh } \\
\text { melakukan kegiatan } \\
\text { kemasyarakatan, laki-laki boleh } \\
\text { melakukan kegiatan } \\
\text { kemasyarakatan }\end{array}$ & Setuju & 4 & 13 \\
\hline $\begin{array}{l}\text { Perempuan memiliki kemampuan } \\
\text { bekerja yang kurang baik, laki- } \\
\text { laki memiliki kemampuan bekerja } \\
\text { yang baik }\end{array}$ & Setuju & 6 & 20 \\
\hline $\begin{array}{l}\text { Perempuan hanya mampu } \\
\text { melakukan pekerjaan yang } \\
\text { mudah, laki-laki mampu } \\
\text { mengerjakan pekerjaan yang sulit }\end{array}$ & Setuju & 7 & 23 \\
\hline $\begin{array}{l}\text { Laki-laki tidak boleh } \\
\text { mengerjakan pekerjaan domestik, } \\
\text { perempuan harus mengerjakan } \\
\text { pekerjaan domestik }\end{array}$ & Setuju & 7 & 23 \\
\hline
\end{tabular}

\begin{tabular}{|c|c|c|c|}
\hline $\begin{array}{l}\text { Perempuan boleh bekerja di luar } \\
\text { rumah namun dengan izin suami, } \\
\text { laki-laki boleh bekerja di luar } \\
\text { rumah tanpa harus dengan izin } \\
\text { istri }\end{array}$ & Setuju & 9 & 30 \\
\hline $\begin{array}{l}\text { Anak laki-laki superior harus } \\
\text { didahulukan, anak perempuan } \\
\text { inferior dinomorduakan }\end{array}$ & Setuju & 9 & 30 \\
\hline $\begin{array}{l}\text { Posisi tertinggi dalam pekerjaan } \\
\text { sebaiknya dipegang oleh laki-laki } \\
\text { dan posisi perempuan di bawah } \\
\text { laki-laki }\end{array}$ & Setuju & 10 & 33 \\
\hline $\begin{array}{l}\text { Perempuan tidak boleh bekerja di } \\
\text { luar rumah, laki-laki boleh } \\
\text { bekerja di luar rumah }\end{array}$ & Setuju & 11 & 37 \\
\hline $\begin{array}{l}\text { Perempuan tidak kuat dalam } \\
\text { mengahadapi persaingan dunia } \\
\text { kerja, laki-laki kuat dalam } \\
\text { menghadapi persaingan dunia } \\
\text { kerja }\end{array}$ & Setuju & 11 & 37 \\
\hline $\begin{array}{l}\text { Laki-laki mampu bekerja } \\
\text { mandiri, perempuan tergantung } \\
\text { kepada suami }\end{array}$ & Setuju & 13 & 43 \\
\hline $\begin{array}{l}\text { Pekerjaan perempuan ialah di } \\
\text { dalam rumah mengurus keluarga } \\
\text { dan anak, pekerjaan laki-laki di } \\
\text { luar rumah mencari nafkah }\end{array}$ & Setuju & 18 & 60 \\
\hline
\end{tabular}

Perempuan mengabdi kepada suami, laki-laki diabdi oleh istri Setuju $20 \quad 67$

\begin{tabular}{llll}
\hline $\begin{array}{l}\text { Perempuan adalah pekerja } \\
\text { rumahan dan laki-laki pencari } \\
\text { nafkah }\end{array}$ & Setuju & 22 & 73 \\
\hline $\begin{array}{l}\text { Perempuan melayani suami, } \\
\text { suami dilayani oleh istri }\end{array}$ & Setuju & 24 & 80 \\
\hline
\end{tabular}

Terdapat 67 persen responden juga sepakat untuk pernyataan mengenai perempuan mengabdi kepada suami, laki-laki diabdi oleh istri, begitu pula mengenai pandangan bahwa perempuan melayani suami, suami dilayani oleh istri disetujui oleh 80 persen responden.

Tabel 4. Jumlah dan Persentase Ideologi Gender yang Melekat pada Responden

\begin{tabular}{clrr}
\hline \multirow{2}{*}{ Kategorisasi Peubah } & Kategorisasi & \multicolumn{2}{c}{ Jumlah } \\
\cline { 3 - 4 } & Sub-peubah & $\mathrm{n}$ & $\%$ \\
\hline \multirow{2}{*}{ Ideologi Gender } & Positif & 20 & 67 \\
& Negatif & 10 & 33 \\
\cline { 2 - 4 } & Jumlah (N) & 30 & 100 \\
\hline
\end{tabular}

Secara lebih spesifik, ideologi gender yang melekat pada responden dengan memperhitungkan pandangan-pandangan responden sebelumnya mengenai peran dan posisi antara laki-laki dan perempuan dapat dilihat pada tabel 4. Hasil penelitian menunjukkan bahwa hanya sebesar 33 persen responden yang memiliki ideologi gender negatif atau pandangan yang mencerminkan struktur patriarkal, yaitu keberpihakan pada laki-laki bahwa peran kerja dan posisi perempuan berbeda dengan laki-laki yang menciptakan ketimpangan diantara keduanya.

Sedangkan mayoritas atau sebesar 67 persen responden memiliki ideologi gender positif yang menunjukkan adanya pemikiran relatif tidak ada perbedaan peran kerja serta posisi antara laki-laki dan perempuan yang mengarah pada kesetaraan dan keadilan gender. Hal tersebut mengartikan bahwa responden tidak menganut pandangan bahwa peran laki-laki dalam sektor publik dan perempuan dalam sektor domestik.

\section{Pengetahuan Responden tentang Kekerasan}

Hasil penelitian yang dapat dilihat pada Tabel 5 diatas, menunjukkan bahwa mayoritas responden memiliki pengetahuan tinggi terhadap kekerasan mengartikan bahwa mayoritas responden menyetujui halhal yang terkait dengan kekerasan. Pengetahuan mengenai kekerasan terhadap perempuan yang rendah hanya terjadi di beberapa hal saja. Pernyataan tersebut tidak disetujui oleh mayoritas responden, diantaranya mengenai setiap orang yang memungkinkan mendapatkan kekerasan, perempuan/istri harus selalu merahasiakan kekerasan yang dialami olehnya, kekerasan merupakan masalah internal serta orang lain tidak perlu ikut mencampuri, dan kekerasan yang dilakukan oleh seorang suami merupakan hal yang wajar untuk mengoreksi istri yang salah. Pernyataan tersebut masing-masing tidak disetujui oleh 
sebesar 57 persen, 70 persen, 73 persen, dan 80 persen responden.

Tabel 5. Jumlah dan Persentase Pengetahuan Responden Mengenai Hal-hal Terkait dengan Kekerasan

\begin{tabular}{|c|c|c|c|}
\hline \multirow[t]{2}{*}{ Pernyataan } & \multirow{2}{*}{$\begin{array}{l}\text { Kategorisasi } \\
\text { Sub-peubah }\end{array}$} & \multicolumn{2}{|c|}{ Jumlah } \\
\hline & & $\mathrm{n}$ & $\%$ \\
\hline $\begin{array}{l}\text { Kekerasan dapat menimbulkan trauma pada } \\
\text { korbannya }\end{array}$ & Setuju & 30 & 100 \\
\hline $\begin{array}{l}\text { Bantuan/dukungan dapat berasal dari } \\
\text { lembaga-lembaga yang bergerak di bidang } \\
\text { sosial (seperti lembaga bantuan hukum) }\end{array}$ & Setuju & 29 & 97 \\
\hline $\begin{array}{l}\text { Bantuan/dukungan dapat berasal dari } \\
\text { tenaga kesehatan }\end{array}$ & Setuju & 28 & 93 \\
\hline Stres dapat menjadi pemicu kekerasan & Setuju & 27 & 90 \\
\hline $\begin{array}{l}\text { Bantuan/dukungan dapat berasal dari orang } \\
\text { tua, saudara, tetangga, dan tokoh setempat }\end{array}$ & Setuju & 27 & 90 \\
\hline $\begin{array}{l}\text { Kekerasan lebih sering dilakukan oleh laki- } \\
\text { laki }\end{array}$ & Setuju & 24 & 80 \\
\hline $\begin{array}{l}\text { Penggunaan alkohol dapat memicu } \\
\text { terjadinya kekerasan }\end{array}$ & Setuju & 24 & 80 \\
\hline $\begin{array}{l}\text { Perempuan lebih sering menjadi korban } \\
\text { kekerasan }\end{array}$ & Setuju & 23 & 77 \\
\hline $\begin{array}{l}\text { Pengangguran dapat lebih memicu resiko } \\
\text { kekerasan }\end{array}$ & Setuju & 23 & 77 \\
\hline $\begin{array}{l}\text { Dukungan dan bantuan dari orang lain } \\
\text { dapat mengurangi rasa putus asa korban } \\
\text { kekerasan }\end{array}$ & Setuju & 23 & 77 \\
\hline $\begin{array}{l}\text { Keluarga yang kurang harmonis menjadi } \\
\text { pemicu kekerasan dalam rumahtangga }\end{array}$ & Setuju & 22 & 73 \\
\hline $\begin{array}{l}\text { Melukai secara fisik (memukul) merupakan } \\
\text { contoh bentuk kekerasan }\end{array}$ & Setuju & 20 & 67 \\
\hline $\begin{array}{l}\text { Sengaja membiarkan anggota keluarga } \\
\text { terlantar tanpa diberikan nafkah adalah } \\
\text { bentuk kekerasan dalam rumahtangga }\end{array}$ & Setuju & 20 & 67 \\
\hline $\begin{array}{l}\text { Memaksa seorang istri untuk melayani } \\
\text { kebutuhan seksual suami ketika istri sedang } \\
\text { tidak siap secara fisik dan psikologis } \\
\text { merupakan bentuk kekerasan dalam dalam } \\
\text { rumahtangga }\end{array}$ & Setuju & 19 & 63 \\
\hline $\begin{array}{l}\text { Nikah dini lebih beresiko mengalami } \\
\text { kekerasan dalam rumahtangga }\end{array}$ & Setuju & 19 & 63 \\
\hline $\begin{array}{l}\text { Pendapatan rumahtangga rendah dapat } \\
\text { lebih memicu resiko kekerasan dalam } \\
\text { rumahtangga }\end{array}$ & Setuju & 18 & 60 \\
\hline $\begin{array}{l}\text { Perkataan yang menimbulkan ketakutan, } \\
\text { tidak berdaya seperti menghina, kata-kata } \\
\text { kasar merupakan contoh bentuk kekerasan }\end{array}$ & Setuju & 18 & 60 \\
\hline $\begin{array}{l}\text { Remaja perempuan lebih beresiko } \\
\text { mengalami kekerasan }\end{array}$ & Setuju & 17 & 57 \\
\hline $\begin{array}{l}\text { Keluarga dengan jumlah anak banyak } \\
\text { beresiko terjadi kekerasan dalam } \\
\text { rumahtangga }\end{array}$ & Setuju & 16 & 53 \\
\hline $\begin{array}{l}\text { Pendidikan rendah dapat lebih memicu } \\
\text { resiko kekerasan }\end{array}$ & Setuju & 16 & 53 \\
\hline $\begin{array}{l}\text { Membatasi ruang gerak (isolasi) atau } \\
\text { melarang istri untuk bersosialisasi dengan } \\
\text { orang lain adalah bentuk kekerasan dalam } \\
\text { rumahtangga }\end{array}$ & Setuju & 16 & 53 \\
\hline $\begin{array}{l}\text { Setiap orang memungkinkan mendapatkan } \\
\text { kekerasan }\end{array}$ & Setuju & 13 & 43 \\
\hline $\begin{array}{l}\text { Perempuan/Istri harus selalu merahasiakan } \\
\text { kekerasan yang dialami olehnya }\end{array}$ & Setuju & 9 & 30 \\
\hline $\begin{array}{l}\text { Kekerasan merupakan masalah internal dan } \\
\text { orang lain tidak perlu ikut mencampuri }\end{array}$ & Setuju & 8 & 27 \\
\hline $\begin{array}{l}\text { Kekerasan yang dilakukan oleh seorang } \\
\text { suami merupakan hal yang wajar untuk } \\
\text { mengoreksi istri yang salah }\end{array}$ & Setuju & 6 & 20 \\
\hline
\end{tabular}

Dapat digambarkan lebih spesifik pada Tabel 6 bahwa mayoritas responden memiliki pengetahuan tentang kekerasan yang tinggi dengan persentase sebesar 90 persen. Hanya sebesar 10 persen saja dari keseluruhan jumlah persentase responden yang tidak menyetujui halhal yang terkait dengan kekerasan. Hal ini mampu menguatkan Tabel 5 bahwa mayoritas responden menyetujui hal-hal yang terkait dengan kekerasan.

Tabel 6. Jumlah dan Persentase Pengetahuan Responden terhadap Kekerasan

\begin{tabular}{clrr}
\hline Kategorisasi & Kategorisasi & Jumlah & \\
\cline { 3 - 4 } Peubah & Sub-peubah & $\mathrm{n}$ & $\%$ \\
\hline Pengetahuan & Rendah & 3 & 10 \\
tentang kekerasan & Tinggi & 24 & 90 \\
\cline { 2 - 4 } & Jumlah $(\mathrm{N})$ & 30 & 100 \\
\hline
\end{tabular}

\section{Kekerasan yang Dialami Responden}

Merujuk pada Poerwandari (2000) mengenai gambaran umum kekerasan terhadap perempuan seperti kekerasan fisik, psikis, seksual, dan finansial/ekonomi, pada Tabel 7 disajikan jumlah dan persentase kekerasan yang dialami responden. Kekerasan yang dibahas pada penelitian ini tidak mengukur sampai sejauh mana tingkat kekerasan tersebut bagi responden. Hal tersebut dikarenakan sangat sensitif dan responden memiliki hak untuk dilindungi sesuai UU pasal 13 tahun 2006 mengenai perlindungan terhadap saksi dan korban. Dalam hal ini responden memiliki hak untuk merahasiakan identitas serta pengalaman pahit yang pernah mereka rasakan. Oleh karena itu, penelitian ini hanya akan membahas jenis kekerasannya tanpa mendeskripsikan lebih lanjut sejauh mana tingkat kekerasan tersebut dialami dan dirasakan oleh responden.

Hasil penelitian menunjukkan bahwa 50 persen responden mengalami lebih dari satu jenis kekerasan. Sebanyak 20 persen responden lainnya mengalami kekerasan fisik, diikuti dengan kekerasan ekonomi sebanyak 10 persen. Sisanya untuk kekerasan psikis dan seksual dirasakan oleh masing-masing sebanyak 17 persen dan 3 persen responden.

Tabel 7. Jumlah dan Persentase Jenis Kekerasan yang Dialami Responden

\begin{tabular}{|c|c|c|}
\hline \multirow{2}{*}{ Kekerasan yang dialami } & \multicolumn{2}{|c|}{ Jumlah } \\
\hline & $\mathrm{n}$ & $\%$ \\
\hline $\begin{array}{l}\text { Fisik (kekerasan dengan benda/alat di } \\
\text { bagian atas tubuh) }\end{array}$ & 6 & 20 \\
\hline Psikis & 5 & 17 \\
\hline Seksual & 1 & 3 \\
\hline Ekonomi & 3 & 10 \\
\hline $\begin{array}{l}\text { Lebih dari satu kekerasan (Fisik- } \\
\text { psikis, psikis-ekonomi, psikis-seksual, } \\
\text { fisik, psikis, ekonomi) }\end{array}$ & 15 & 50 \\
\hline Jumlah $(\mathrm{N})$ & 30 & 100 \\
\hline
\end{tabular}


Tabel 8. Jumlah dan Persentase Hubungan Usia dengan Kekerasan yang Dialami Responden

\begin{tabular}{|c|c|c|c|c|c|c|c|c|c|c|c|c|}
\hline \multirow{4}{*}{$\begin{array}{c}\text { Usia } \\
\text { Korban }\end{array}$} & \multicolumn{10}{|c|}{ Kekerasan yang dialami } & \multirow{3}{*}{\multicolumn{2}{|c|}{ Total }} \\
\hline & \multirow{2}{*}{\multicolumn{2}{|c|}{ fisik }} & \multirow{2}{*}{\multicolumn{2}{|c|}{ psikis }} & \multirow{2}{*}{\multicolumn{4}{|c|}{$\begin{array}{l}\text { Ekonomi } \\
\text { seksual }\end{array}$}} & \multirow{2}{*}{\multicolumn{2}{|c|}{$\begin{array}{c}>1 \\
\text { kekerasan }\end{array}$}} & & \\
\hline & & & & & & & & & & & & \\
\hline & $\mathrm{n}$ & $\%$ & $\mathrm{n}$ & $\%$ & $\mathrm{n}$ & $\%$ & $\mathrm{n}$ & $\%$ & $\mathrm{n}$ & $\%$ & $\mathrm{n}$ & $\%$ \\
\hline $\begin{array}{l}\text { muda } \\
(<30)\end{array}$ & & 33,3 & 0 & 0 & 1 & 100 & 0 & 0 & 2 & 13,3 & 5 & 16,7 \\
\hline $\begin{array}{l}\text { madya } \\
(30-55)\end{array}$ & & 66,7 & 4 & 80 & 0 & 0 & 2 & 66,7 & 12 & 80 & 22 & 73,3 \\
\hline $\begin{array}{l}\text { tua } \\
(>55)\end{array}$ & 0 & 0 & 1 & 20 & 0 & 0 & 1 & 33.3 & 1 & 6.7 & 3 & 10 \\
\hline Total & 6 & 100 & 5 & 100 & 1 & 100 & 3 & 100 & 15 & 100 & 30 & 100 \\
\hline
\end{tabular}

Tabel 9. Jumlah dan Persentase Hubungan Pendidikan Terakhir dengan Kekerasan yang Dialami Responden

\begin{tabular}{|c|c|c|c|c|c|c|c|c|c|c|}
\hline \multirow{3}{*}{$\begin{array}{c}\text { Pendidikan } \\
\text { Terakhir }\end{array}$} & \multicolumn{8}{|c|}{ Kekerasan yang dialami } & \multirow{2}{*}{\multicolumn{2}{|c|}{ Total }} \\
\hline & fisik & \multicolumn{2}{|c|}{ psikis } & \multicolumn{5}{|c|}{$\begin{array}{c}>1 \\
\text { seksual Ekonomi kekerasan }\end{array}$} & & \\
\hline & $\mathrm{n} \quad \%$ & $\mathrm{n}$ & $\%$ & $\mathrm{n}$ & $\%$ & $\mathrm{n}$ & $\%$ & $\%$ & $\mathrm{n}$ & $\%$ \\
\hline$<6$ tahun & 0 & 0 & 0 & 0 & 0 & 1 & 33,3 & 213,3 & 3 & 10 \\
\hline 6-9 tahun & 583,3 & 2 & 40 & 1 & 100 & 1 & 33,3 & 426,7 & 13 & 43,3 \\
\hline$>9$ tahun & 116,7 & 3 & 60 & 0 & 0 & 1 & 33,3 & 60 & 14 & 46,7 \\
\hline Total & $6 \quad 100$ & 5 & 100 & 1 & 100 & 3 & 100 & 15100 & 30 & 100 \\
\hline
\end{tabular}

Responden dengan Kekerasan yang Dialami Responden Kekerasan yang dialami jika dihubungkan dengan karakteristik responden mengenai usia, pendidikan terakhir, dan status pernikahan responden masing-masing dapat dilihat pada Tabel 8, 9, dan 10.

Tabel 10. Jumlah dan Persentase Hubungan Status Pernikahan dengan Kekerasan yang Dialami Responden

\begin{tabular}{|c|c|c|c|c|c|c|c|c|c|c|c|}
\hline \multirow{4}{*}{$\begin{array}{c}\text { Status } \\
\text { Pernikahan }\end{array}$} & \multicolumn{9}{|c|}{ Kekerasan yang dialami } & \multirow{3}{*}{\multicolumn{2}{|c|}{ Total }} \\
\hline & \multirow[b]{2}{*}{ fisik } & \multirow{2}{*}{\multicolumn{2}{|c|}{ psikis }} & \multirow{2}{*}{\multicolumn{2}{|c|}{ Seksual }} & \multirow{2}{*}{\multicolumn{2}{|c|}{ Ekonomi }} & \multirow{2}{*}{\multicolumn{2}{|c|}{$\begin{array}{c}>1 \\
\text { kekerasan }\end{array}$}} & & \\
\hline & & & & & & & & & & & \\
\hline & $\mathrm{n} \quad \%$ & $\mathrm{n}$ & $\%$ & $\mathrm{n}$ & $\%$ & $\mathrm{n}$ & $\%$ & $\mathrm{n}$ & $\%$ & $\mathrm{n}$ & $\%$ \\
\hline Blm menikah & 116,7 & 0 & 0 & 0 & 0 & 0 & 0 & 0 & 0 & 1 & 3,3 \\
\hline Menikah & 116,7 & 1 & 20 & 0 & 0 & 0 & 0 & 6 & 40 & 8 & 26,7 \\
\hline Cerai & 350 & 4 & 80 & 1 & 100 & 3 & 100 & 9 & 60 & 20 & 66,7 \\
\hline $\begin{array}{l}\text { Menunggu } \\
\text { putusan } \\
\text { pengadilan }\end{array}$ & 116,7 & 0 & 0 & 0 & 0 & 0 & 0 & 0 & 0 & 1 & 3,3 \\
\hline Total & 6100 & 5 & 100 & 1 & 100 & 3 & 100 & 15 & 100 & 30 & 100 \\
\hline
\end{tabular}

Tabel 11. Jumlah dan Persentase Hubungan Pelaku dengan Kekerasan yang Dialami Responden

\begin{tabular}{|c|c|c|c|c|c|c|c|c|c|c|c|c|}
\hline \multirow{3}{*}{$\begin{array}{l}\text { Hub. Pelaku } \\
\text { dengan } \\
\text { Responden }\end{array}$} & \multicolumn{10}{|c|}{ Kekerasan yang dialami } & \multirow{2}{*}{\multicolumn{2}{|c|}{ Total }} \\
\hline & \multicolumn{2}{|c|}{ fisik } & \multicolumn{2}{|c|}{ psikis } & \multicolumn{2}{|c|}{ seksual } & \multicolumn{2}{|c|}{ Ekonomi } & \multicolumn{2}{|c|}{$\begin{array}{c}>1 \\
\text { kekerasan }\end{array}$} & & \\
\hline & $\mathrm{n}$ & $\%$ & $\mathrm{n}$ & $\%$ & $\mathrm{n}$ & $\%$ & $\mathrm{n}$ & $\%$ & $\mathrm{n}$ & $\%$ & $\mathrm{n}$ & $\%$ \\
\hline Suami & 5 & 83,3 & 4 & 80 & 0 & 0 & 3 & 100 & 14 & 93,3 & 268 & 86,7 \\
\hline $\begin{array}{l}\text { Lainnya } \\
\text { (pacar, } \\
\text { atasan kerja) }\end{array}$ & 1 & 16,7 & 1 & 20 & 1 & 100 & 0 & 0 & 1 & 6,7 & & 13,3 \\
\hline Total & 6 & 100 & 5 & 100 & 1 & 100 & 3 & 100 & 15 & 100 & 30 & 100 \\
\hline
\end{tabular}

Tabel 12. Jumlah dan Persentase Hubungan Usia Pelaku dengan Kekerasan yang Dialami Responden

\begin{tabular}{|c|c|c|c|c|c|c|c|c|c|c|c|c|}
\hline \multirow{4}{*}{ Usia Pelaku } & \multicolumn{10}{|c|}{ Kekerasan yang dialami Responden } & \multirow{3}{*}{\multicolumn{2}{|c|}{ Total }} \\
\hline & \multirow{2}{*}{\multicolumn{2}{|c|}{ fisik }} & \multirow{2}{*}{\multicolumn{2}{|c|}{ Psikis }} & \multirow{2}{*}{\multicolumn{2}{|c|}{ seksual }} & \multirow{2}{*}{\multicolumn{2}{|c|}{ Ekonomi }} & \multirow{2}{*}{\multicolumn{2}{|c|}{$\begin{array}{c}>1 \\
\text { kekerasan }\end{array}$}} & & \\
\hline & & & & & & & & & & & & \\
\hline & $\mathrm{n}$ & $\%$ & $\mathrm{n}$ & $\%$ & $\mathrm{n}$ & $\%$ & $\mathrm{n}$ & $\%$ & $\mathrm{n}$ & $\%$ & $\mathrm{n}$ & $\%$ \\
\hline muda $(<30)$ & 2 & 33,3 & 0 & 0 & 1 & 100 & 0 & 0 & 1 & 6,7 & 4 & 13,3 \\
\hline $\begin{array}{l}\text { madya (30- } \\
55)\end{array}$ & 3 & 50 & 4 & 80 & 0 & 0 & 2 & 66,7 & 11 & 73,3 & 20 & 66,7 \\
\hline tua $(>55)$ & 1 & 16,7 & 1 & 20 & 0 & 0 & 1 & 33.3 & 3 & 20 & 6 & 20 \\
\hline Total & 6 & 100 & 5 & 100 & 1 & 100 & 3 & 100 & 15 & 100 & 30 & 100 \\
\hline
\end{tabular}

\section{HUBUNGAN ANTAR VARIABEL TERKAIT KEKERASAN TERHADAP PEREMPUAN}

\section{Hubungan Ideologi Gender yang Melekat pada Responden dengan Kekerasan yang Dialami Responden}

Dari Tabel 13 berikut, dapat digambarkan bahwa mayoritas responden mendapatkan lebih dari satu jenis kekerasan dan memiliki ideologi gender positif (sebesar 66,7 persen). Namun, secara merata kekerasan juga dialami oleh responden dengan kedua idelogi tersebut, baik positif maupun negatif. Berdasarkan hasil analisis uji statistik Chi-square antara ideologi gender yang melekat pada responden dengan kekerasan yang dialami responden, tingkat signifikansi yang dihasilkan $0.8>0.05$ level of significant $(\alpha)$. Hal ini menunjukkan bahwa hubungan antara kedua variabel tidak signifikan. Artinya tidak terdapat hubungan antara ideologi gender yang melekat pada responden dengan kekerasan yang dialami responden. Responden pada umumnya tidak menyetujui adanya persepsi yang membedakan peran laki-laki dan perempuan di masyarakat, namun kenyataannya mereka tetap menjadi korban tindak kekerasan.

Hasil penelitan pada bagian ini tidak sejalan dengan rujukan teori-teori yang telah disebutkan sebelumnya. Hal tersebut dikarenakan pada dasarnya ideologi gender yang berhubungan dengan kekerasan yang dialami responden tidak dapat dilihat hanya dari sisi responden saja. Namun, juga perlu dilihat dari sisi pelaku kekerasan dan lingkungan masyarakatnya. Hal inilah yang menjadi limitasi penelitian pada bagian ini. Selain itu, walaupun kekerasan yang dialami oleh responden bukanlah suatu hal yang disetujui ataupun diinginkan oleh 
semua orang khususnya perempuan, namun penolakan terhadap tindak kekerasan bukanlah suatu hal yang mudah dilakukan. Perempuan yang sudah sadar gender dan berpendidikan tinggi sekalipun, seperti mayoritas responden pada penelitian ini, tetap saja berpotensi untuk mengalami tindak kekerasan. Apalagi jika keadaan yang ada adalah sebaliknya. Pada akhirnya kekerasan terhadap perempuan tetap saja marak terjadi.

Tabel 13. Jumlah dan Persentase Hubungan Ideologi Gender yang Melekat pada Responden dengan Kekerasan yang dialami Responden

\begin{tabular}{|c|c|c|c|c|c|c|c|c|c|c|c|c|}
\hline \multirow{3}{*}{$\begin{array}{l}\text { Ideol } \\
\text { ogi } \\
\text { Gend } \\
\text { er }\end{array}$} & \multicolumn{10}{|c|}{ Kekerasan yang dialami } & \multirow{2}{*}{\multicolumn{2}{|c|}{ Total }} \\
\hline & \multicolumn{2}{|c|}{ Fisik } & \multicolumn{2}{|c|}{ Psikis } & \multicolumn{2}{|c|}{$\begin{array}{c}\text { Seksua } \\
1\end{array}$} & \multicolumn{2}{|c|}{$\begin{array}{c}\text { Ekono } \\
\text { mi }\end{array}$} & \multicolumn{2}{|c|}{$\begin{array}{c}\text { Lebih } \\
\text { dari } 1 \\
\text { kekeras } \\
\text { an }\end{array}$} & & \\
\hline & $\mathrm{n}$ & $\%$ & $\mathrm{n}$ & $\%$ & $\mathrm{n}$ & $\%$ & $\mathrm{n}$ & $\%$ & $\mathrm{n}$ & $\%$ & $\mathrm{n}$ & $\%$ \\
\hline $\begin{array}{l}\text { Positi } \\
\mathrm{f}\end{array}$ & 3 & 50 & 4 & 80 & 1 & $\begin{array}{c}10 \\
0\end{array}$ & 2 & $\begin{array}{c}66, \\
7\end{array}$ & $\begin{array}{l}1 \\
0\end{array}$ & $\begin{array}{c}66, \\
7\end{array}$ & $\begin{array}{l}2 \\
0\end{array}$ & $\begin{array}{c}66, \\
7\end{array}$ \\
\hline $\begin{array}{l}\text { Negat } \\
\text { if }\end{array}$ & 3 & 50 & 1 & 20 & 0 & 0 & 1 & $\begin{array}{c}33, \\
3\end{array}$ & 5 & $\begin{array}{c}33, \\
3\end{array}$ & $\begin{array}{l}1 \\
0\end{array}$ & $\begin{array}{c}33, \\
3\end{array}$ \\
\hline Total & 6 & $\begin{array}{c}10 \\
0\end{array}$ & 5 & $\begin{array}{c}10 \\
0\end{array}$ & 1 & $\begin{array}{c}10 \\
0\end{array}$ & 3 & $\begin{array}{c}10 \\
0\end{array}$ & $\begin{array}{l}1 \\
5\end{array}$ & $\begin{array}{c}10 \\
0\end{array}$ & $\begin{array}{l}3 \\
0\end{array}$ & $\begin{array}{c}10 \\
0\end{array}$ \\
\hline
\end{tabular}

* $\quad$ signifikansi/ $\alpha=0,8$

\section{Hubungan Pengetahuan tentang kekerasan yang Melekat pada Responden dengan Kekerasan yang Dialami Responden}

Pada bagian ini, akan dibahas mengenai ada tidaknya hubungan antara pengetahuan responden terhadap kekerasan dengan kekerasan yang dialami responden. Pengetahuan responden mengenai siapa yang lebih sering menjadi korban dan pelaku kekerasan, pemicu kekerasan, serta bantuan yang memungkinkan ketika terjadi kekerasan seperti tergambar pada Tabel 14 dengan kekerasan yang dialami oleh responden. Dapat dijelaskan bahwa mayoritas responden yang mengalami lebih dari satu jenis kekerasan dan memiliki pengetahuan tentang kekerasan kuat dengan persentase terbesar yaitu 86,7 persen. Begitu pula dengan responden yang mengalami 83,3 persen kekerasan fisik, 80 persen seksual, dan 66,7 persen penelataran ekonomi.

Artinya adanya pengetahuan responden yang kuat mengenai perempuan sebagai korban, laki-laki sebagai pelaku kekerasan, pemicu kekerasan, serta bantuan yang memungkinkan ketika terjadi kekerasan yang disetujui oleh mayoritas responden berhubungan dengan kekerasan yang dialami oleh responden. Kesimpulan tersebut diperkuat dengan hasil analisis uji statistik Chi-square antara pengetahuan tentang kekerasan yang melekat pada responden dengan kekerasan yang dialami responden. Tingkat signifikansi yang dihasilkan $0,03<0.05$ level of significant $(\alpha)$. Hal ini menunjukkan bahwa hubungan antara kedua variabel signifikan. Artinya terdapat hubungan antara pengetahuan tentang kekerasan yang melekat pada responden dengan kekerasan yang dialami responden.
Tabel 14. Jumlah dan persentase Hubungan antara Pengetahuan tentang kekerasan yang Melekat pada Responden dengan Kekerasan yang Dialami Responden

\begin{tabular}{|c|c|c|c|c|c|c|c|c|c|c|c|c|}
\hline \multirow{3}{*}{$\begin{array}{l}\text { Pengeta } \\
\text { huan } \\
\text { tentang } \\
\text { kekeras } \\
\text { an }\end{array}$} & \multicolumn{10}{|c|}{ Kekerasan yang dialami } & & \\
\hline & \multicolumn{2}{|c|}{ Fisik } & \multicolumn{2}{|c|}{ Psikis } & \multicolumn{2}{|c|}{$\begin{array}{c}\text { Seksu } \\
\text { al }\end{array}$} & \multicolumn{2}{|c|}{$\begin{array}{c}\text { Ekono } \\
\text { mi }\end{array}$} & \multicolumn{2}{|c|}{$\begin{array}{c}\text { Lebih } \\
\text { dari } 1 \\
\text { kekeras } \\
\text { an }\end{array}$} & \multicolumn{2}{|c|}{ Total } \\
\hline & $\mathrm{n}$ & $\%$ & $\mathrm{n}$ & $\%$ & $\mathrm{n}$ & $\%$ & & $\%$ & $\mathrm{n}$ & $\%$ & $\mathrm{~N}$ & $\%$ \\
\hline Lemah & 0 & $\begin{array}{l}16 \\
, 7\end{array}$ & 0 & 20 & 1 & $\begin{array}{c}10 \\
0\end{array}$ & 0 & $\begin{array}{c}33 \\
3\end{array}$ & 2 & $\begin{array}{l}33 \\
3\end{array}$ & 3 & 10 \\
\hline Kuat & 6 & $\begin{array}{r}83 \\
, 3\end{array}$ & 5 & 80 & 0 & 0 & 3 & $\begin{array}{c}66 \\
7\end{array}$ & $\begin{array}{l}1 \\
3\end{array}$ & $\begin{array}{c}86 \\
, 7\end{array}$ & $\begin{array}{l}2 \\
7\end{array}$ & 90 \\
\hline Total & 6 & $\begin{array}{c}10 \\
0\end{array}$ & 5 & $\begin{array}{c}10 \\
0\end{array}$ & 1 & $\begin{array}{c}10 \\
0\end{array}$ & 3 & $\begin{array}{c}10 \\
0\end{array}$ & $\begin{array}{l}1 \\
5\end{array}$ & $\begin{array}{c}10 \\
0\end{array}$ & $\begin{array}{l}3 \\
0\end{array}$ & $\begin{array}{c}10 \\
0\end{array}$ \\
\hline
\end{tabular}

* $\quad$ signifikansi/ $\alpha=0,03$

\section{STRATEGI PENDAMPINGAN OLEH P2TP2A DKI JAKARTA}

\section{Pendampingan yang Diberikan oleh P2TP2A DKI Jakarta}

Pada bagian ini akan dijabarkan lebih lanjut mengenai sejauh mana pendampingan ataupun pelayanan P2TP2A yang dirasakan oleh responden. Dapat diketahui bahwa hasil penelitian menunjukkan P2TP2A DKI Jakarta telah memberikan pelayanan hukum berupa proses hukum bagi pelaku tindak kekerasan, memberikan perlindungan dan konsultasi hukum bagi responden, menjadi pendamping (kuasa hukum) dalam proses di tingkat kepolisian, kejaksaan, dan pengadilan. Selain itu juga, memberikan pelayanan psikologis berupa mempertemukan dengan kelompok dukungan (sesama korban) serta memberikan pelayanan yang bersifat mendidik berupa kegiatan-kegiatan pelatihan.

Tabel 16. Jumlah dan Persentase Keseluruhan Pendampingan P2TP2A DKI Jakarta

\begin{tabular}{llcr}
\hline \multicolumn{1}{c}{ Kategorisasi } & Kategorisasi & \multicolumn{2}{c}{ Jumlah } \\
\cline { 3 - 4 } Peubah & Sub-peubah & $\mathrm{n}$ & $\%$ \\
\hline Pendampingan & Rendah & 0 & 0 \\
P2TP2A yang & Tinggi & 30 & 100 \\
\cline { 2 - 4 } Diterima & Jumlah (N) & 30 & 100 \\
Responden & & &
\end{tabular}

Pada Tabel 16 ini menggambarkan bahwa keseluruhan bentuk pendampingan diterima dan dirasakan tinggi oleh 100 persen responden. Hal ini membuktikan bahwa secara umum P2TP2A DKI Jakarta telah melakukan pendampingan terhadap perempuan korban tindak kekerasan sesuai dengan fungsi peran, tugas, dan tanggungjawabnya. 
Tabel 15. Jumlah dan Persentase Bentuk Pendampingan P2TP2A DKI Jakarta yang Dirasakan Oleh Responden

\begin{tabular}{|c|c|c|c|}
\hline \multirow[b]{2}{*}{ Bentuk Pendampingan P2TP2A } & \multirow{2}{*}{$\begin{array}{l}\text { Kategorisasi } \\
\text { Sub-peubah }\end{array}$} & \multicolumn{2}{|c|}{ Jumlah } \\
\hline & & $\mathrm{n}$ & $\%$ \\
\hline $\begin{array}{l}\text { Memberikan pelayanan hukum berupa } \\
\text { proses hukum bagi pelaku tindak } \\
\text { kekerasan. }\end{array}$ & $\mathrm{Ya}$ & 30 & 100 \\
\hline $\begin{array}{l}\text { Memberikan perlindungan dan } \\
\text { konsultasi hukum bagi perempuan } \\
\text { korban tindak kekerasan }\end{array}$ & $\mathrm{Ya}$ & 30 & 100 \\
\hline $\begin{array}{l}\text { Memberikan pendampingan dengan } \\
\text { menjadi kuasa hukum dalam proses di } \\
\text { tingkat kepolisian, kejaksaan, dan } \\
\text { pengadilan }\end{array}$ & Ya & 30 & 100 \\
\hline $\begin{array}{l}\text { Memberikan pelayanan psikologis } \\
\text { berupa mempertemukan dengan } \\
\text { kelompok dukungan (sesama korban) }\end{array}$ & $\mathrm{Ya}$ & 30 & 100 \\
\hline $\begin{array}{l}\text { Memberikan pelayanan yang bersifat } \\
\text { mendidik berupa kegiatan-kegiatan } \\
\text { seperti, pelatihan, seminar, dan } \\
\text { penelitian }\end{array}$ & $\mathrm{Ya}$ & 30 & 100 \\
\hline $\begin{array}{l}\text { Memberikan pelayanan psikologis } \\
\text { berupa pendampingan dan konseling }\end{array}$ & $\mathrm{Ya}$ & 28 & 93 \\
\hline $\begin{array}{l}\text { Memberikan perlindungan sementara } \\
\text { berupa rumah aman yang } \\
\text { keberadaannya dirahasiakan }\end{array}$ & Ya & 24 & 80 \\
\hline $\begin{array}{l}\text { Memberikan pelayanan kesehatan } \\
\text { berupa penanganan luka atau penyakit } \\
\text { akibat kekerasan }\end{array}$ & Ya & 22 & 73 \\
\hline $\begin{array}{l}\text { Memberikan pelayanan kesehatan } \\
\text { berupa rawat jalan dan rawat inap di } \\
\text { rumah sakit ataupun Puskesmas mitra } \\
\text { kerja P2TP2A }\end{array}$ & Ya & 21 & 70 \\
\hline $\begin{array}{l}\text { Memberikan pelayanan kesehatan } \\
\text { pembuatan }\end{array}$ & & & \\
\hline $\begin{array}{l}\text { visum (atas permintaanpolisi) sebagai } \\
\text { alat bukti di pengadilan }\end{array}$ & Ya & 21 & 70 \\
\hline
\end{tabular}

\section{Bentuk Edukasi P2TP2A Kepada Responden}

Salah satu faktor strategi pendampingan keberlanjutan dan kesesuaian dengan kebutuhan pendampingan yang tinggi oleh P2TP2A DKI Jakarta adalah adanya bentuk pendampingan berupa pemberian edukasi. Pemberian edukasi ini dapat dilakukan dengan berbagai cara, salah satunya berupa pelatihan bagi klien lama yang proses perlindungannya hampir atau telah selesai. Salah satu pelatihan yang dilakukan oleh P2TP2A yang bekerja sama dengan Dinas Sosial adalah pelatihan tata boga yang diberikan kepada responden dalam penelitian ini. Pelatihan dilakukan di Yayasan Taruna Eka Bakti dua kali dalam satu tahun dengan intensitas satu minggu setiap kali pelatihan. Pelatih dalam pelatihan ini didatangkan langsung oleh pihak yayasan.

Responden merasakan adanya manfaat psikologis dari pelatihan ini dengan adanya pertemuan antar sesama korban, selain itu juga mereka merasa keterampilan mereka bertambah khususnya dalam hal tata boga. Hal tersebut diperkuat oleh pernyataan salah satu responden (CH/32 tahun) berikut: “...yaaa, seneng aja gitu, ternyata selama ini saya gag sendiri, ada temen-temen juga yang pernah punya pengalaman gag enak kayak saya. Saya juga jadi bisa belajar buat kue-kue. Nambah keterampilan juga kan ya..."

Pernyataan tersebut menunjukkan bahwa pelatihan yang diberikan oleh P2TP2A selain bermanfaat untuk membantu memulihkan kondisi psikologis juga dapat menambah keterampilan tata boga bagi responden. Keberlanjutan dari pelatihan ini juga cukup bagus, P2TP2A bekerja sama dengan Dinas Sosial memberikan modal per orang sejumlah dua juta rupiah yang berupa uang dan peralatan masak termasuk kompor dan tabung gas.

Salah satu faktor yang menentukan keberhasilan program pelatihan tata boga ini juga dipengaruhi karena adanya kemampuan pelatih yang mampu menarik minat peserta. Untuk mengetahui sejauh mana kemampuan yang dimiliki pelatih menurut responden dapat digambarkan pada Tabel 17. Menurut hasil penelitian yang telah digambarkan pada Tabel 17 dapat dikatakan kemampuan pelatih cukup tinggi. Hal tersebut dapat dilihat dari tiga faktor, yaitu dari segi materi yang dimengerti oleh 100 persen responden dengan mengikuti kegiatan tersebut dari awal sampai akhir. Untuk mempraktekkan ilmu yang telah diberikan pada saat pelatihan hanya dilakukan oleh 73 persen responden saja.

Tabel 17. Jumlah dan Persentase Kemampuan Pelatih Menurut Responden

\begin{tabular}{llrr}
\hline \multirow{2}{*}{ Kemampuan Pelatih } & Kategorisasi & \multicolumn{2}{c}{ Jumlah } \\
\cline { 3 - 4 } & Sub-peubah & $\mathrm{n}$ & Persen \\
\hline \multirow{3}{*}{$\begin{array}{l}\text { Materi dimengerti oleh } \\
\text { peserta }\end{array}$} & Rendah & 0 & 0 \\
& Sedang & 0 & 0 \\
& Tinggi & 30 & 100 \\
\cline { 2 - 4 } & Jumlah (N) & 30 & 100 \\
\hline \multirow{3}{*}{$\begin{array}{l}\text { Peserta mengikuti kegiatan } \\
\text { dari awal sampai akhir }\end{array}$} & Rendah & 0 & 0 \\
& Sedang & 0 & 0 \\
\hline Peserta mampu & Tinggi & 30 & 100 \\
\cline { 2 - 4 } mempraktekkan teori & Jumlah (N) & 30 & 100 \\
dalam kehidupan sehari- & Rendah & 0 & 0 \\
hari & Sedang & 8 & 27 \\
& Tinggi & 22 & 73 \\
\cline { 2 - 4 } & Jumlah (N) & 30 & 100 \\
\hline
\end{tabular}

\section{Kemampuan/Daya Pulih Responden}

Strategi dan bentuk-bentuk pendampingan oleh P2TP2A DKI Jakarta yang telah dijelaskan sebelumnya menjadi salah satu faktor penentu yang penting bagi pulihnya keadaan perempuan korban tindak kekerasan. Keberadaan P2TP2A sendiri sangat dibutuhkan oleh responden baik untuk membantu proses hukum bagi pelaku tindak kekerasan juga bagi pulihnya keadaan psikologis responden.

Untuk mengetahui lebih lanjut kemampuan/daya pulih responden dapat dilihat pada Tabel 18 mengenai jumlah dan persentase bentuk-bentuk kemampuan/daya pulih responden. Kategori rendah merupakan kemampuan yang sangat kurang, sedang untuk kemampuan kurang, dan tinggi untuk kemampuan cukup/bagus. Sejauh ini hasil penelitian menunjukkan sebanyak 7 persen responden merasa kurang dan 93 persen responden 
merasa cukup bagus untuk dapat beraktivitas kembali seperti biasa. Selanjutnya kemampuan untuk sosialisasi dengan keluarga/kerabat dianggap kurang oleh 17 persen responden sedangkan kemampuan cukup/bagus diakui oleh sebesar 83 persen responden. Untuk kemampuan bersosialisasi dengan lingkungan sekitar diakui kurang oleh 23 persen responden, sedangkan untuk yang cukup/bagus diakui oleh 77 persen responden. Selanjutnya secara berturut-turut kemampuan yang sangat kurang, kurang, dan cukup/bagus untuk menceritakan pengalaman pahit yang pernah dirasakan kepada orang lain untuk dijadikan pelajaran diakui oleh masing-masing sebesar 17 persen, 6 persen, dan 77 persen responden.

Tabel 18. Jumlah dan Persentase Bentuk-Bentuk Kemampuan/Daya Pulih Responden

\begin{tabular}{|c|c|c|c|}
\hline \multirow{2}{*}{ Kemampuan Responden } & \multirow{2}{*}{$\begin{array}{l}\text { Kategorisasi } \\
\text { Sub-peubah }\end{array}$} & \multicolumn{2}{|c|}{ Jumlah } \\
\hline & & $\mathrm{n}$ & $\%$ \\
\hline \multirow{4}{*}{$\begin{array}{l}\text { Dapat beraktivitas kembali } \\
\text { seperti biasa }\end{array}$} & Rendah & 0 & 0 \\
\hline & Sedang & 2 & 7 \\
\hline & Tinggi & 28 & 93 \\
\hline & Jumlah (N) & 30 & 100 \\
\hline \multirow{4}{*}{$\begin{array}{l}\text { Bersedia bersosialisasi } \\
\text { dengan keluarga/kerabat }\end{array}$} & Rendah & 0 & 0 \\
\hline & Sedang & 5 & 17 \\
\hline & Tinggi & 25 & 83 \\
\hline & Jumlah (N) & 30 & 100 \\
\hline \multirow{4}{*}{$\begin{array}{l}\text { Bersedia bersosialisasi } \\
\text { dengan lingkungan sekitar }\end{array}$} & Rendah & 0 & 0 \\
\hline & Sedang & 7 & 23 \\
\hline & Tinggi & 23 & 77 \\
\hline & Jumlah (N) & 30 & 100 \\
\hline \multirow{4}{*}{$\begin{array}{l}\text { Bersedia menceritakan } \\
\text { pengalaman pahit yang } \\
\text { pernah dirasakan kepada } \\
\text { orang lain untuk dijadikan } \\
\text { pelajaran }\end{array}$} & Rendah & 5 & 17 \\
\hline & Sedang & 2 & 6 \\
\hline & Tinggi & 23 & 77 \\
\hline & Jumlah (N) & 30 & 100 \\
\hline
\end{tabular}

Dari keseluruhan bentuk kemampuan yang telah dilakukan oleh responden pasca pengalaman pahit yang pernah mereka rasakan dapat disimpulkan bahwa daya pulih responden cukup bagus. Hal tersebut dapat dilihat pada Tabel 19 yang menunjukkan bahwa sebanyak 20 persen responden memiliki daya pulih yang kurang, sedangkan untuk 80 persen responden lainnya memiliki daya pulih yang cukup/bagus.

Tabel 19. Jumlah dan Persentase Kemampuan/Daya Pulih Responden

\begin{tabular}{clrr}
\hline Kategorisasi & Kategorisasi & \multicolumn{2}{c}{ Jumlah } \\
\cline { 3 - 4 } Peubah & Sub-peubah & $\mathrm{n}$ & $\%$ \\
\hline \multirow{3}{*}{ Kemampuan/Daya } & Rendah & 0 & 0 \\
Pulih & Sedang & 6 & 20 \\
& Tinggi & 24 & 80 \\
\cline { 2 - 4 } & Jumlah (N) & 30 & 100 \\
\hline
\end{tabular}

\section{PENUTUP}

\section{Kesimpulan}

P2TP2A sebagai pusat pelayanan terpadu yang menyediakan pelayanan bagi perempuan dan anak korban kekerasan di DKI Jakarta diinformasikan telah menangani sekitar 5931 klien kasus kekerasan dengan klien terbesar perempuan yaitu sebanyak $72 \%$. Dari hasil penelitian diketahui bahwa:
1. Persentase terbesar usia perempuan dampingan P2TP2A yang menjadi responden dalam penelitian ini berada pada usia madya yaitu pada selang antara 3055 tahun. Mayoritas pendidikan terakhir responden mencapai lulus SMA. Responden sebagian besar diketahui pula telah berstatus cerai. Setara dengan responden, pelaku kekerasan mayoritas berusia 30-55 tahun. Pelaku kekerasan merupakan orang terdekat responden yang tidak lain adalah suami responden sendiri yang menunjukkan KDRT masih mendominasi.

2. Mayoritas responden memiliki ideologi gender positif, yakni pandangan terhadap peran gender yang tidak bersifat diskriminatif, subordinatif dan memarginalkan perempuan/laki-laki. Pandangan yang mendukung kesetaraan dan keadilan gender.

3. Pengetahuan responden terhadap kekerasan dapat dikategorikan tinggi. Keadaan tersebut mengartikan bahwa responden menyetujui hal-hal yang terkait dengan kekerasan. Hal tersebut meliputi pernyataan mengenai siapa yang lebih sering menjadi korban dan pelaku, pemicu kekerasan, serta bantuan yang memungkinkan ketika terjadi kekerasan menurut responden.

4. Mayoritas responden mengalami KDRT yang menerima lebih dari satu jenis kekerasan.

5. Pengetahuan mengenai hal-hal yang terkait dengan kekerasan ternyata berhubungan dengan kekerasan yang dialami oleh responden. Namun antara ideologi gender yang dimiliki oleh responden dengan kekerasan yang dialami oleh responden ternyata tidak berhubungan.

6. P2TP2A DKI Jakarta telah melakukan fungsi tugas pendampingan berupa pelayanan hukum, kesehatan, psikologis, rumah aman hingga pemberdayaan berupa pelatihan-pelatihan. Hal tersebut menguatkan bahwa pendampingan yang dilakukan oleh P2TP2A DKI Jakarta dapat dikatakan memiliki intensitas, keberlanjutan, serta kesesuaian dengan kebutuhan korban yang tinggi. P2TP2A DKI Jakarta juga melakukan peningkatan keterampilan di akhir pendampingan dalam usaha memulihkan kondisi psikologis responden dengan cara mempertemukan sesama korban. Bentuknya adalah pelatihan tata boga yang bekerja sama dengan Dinas Sosial. Pelatihan dilakukan di Yayasan Taruna Eka Bakti, dua kali dalam satu tahun dengan intensitas satu minggu setiap kali pelatihan. Faktor-faktor di atas tersebut pada akhirnya mampu meningkatkan daya pulih responden. Hal ini dapat diketahui dari hasil penelitian bahwa sebanyak 80 persen responden memiliki daya pulih yang cukup/bagus.

\section{Saran}

Beberapa hal yang direkomendasikan dalam penelitian ini:

1. Perlu dilakukannya sosialisasi kepada segenap lapisan masyarakat baik melalui media maupun sosialisasi tatap muka oleh pemerintah, LSM dan dinas terkait 
mengenai ancaman bahaya kekerasan yang dapat terjadi di mana-mana dengan pelaku kekerasan yang sangat memungkinkan adalah orang terdekat kita.

2. Perlu dilakukannya pengenalan kepada masyarakat luas akan keberadaan crisis center yang dapat membantu baik secara hukum, fisik, dan psikologis ketika terjadi kekerasan sebagai upaya yang cepat dan tepat dalam menangani sebuah tindakan kekerasan yang terjadi di masyarakat.

3. Perlu dilakukannya pemulihan kesehatan jiwa/mental korban tindak kekerasan berupa kegiatan-kegiatan edukasi dan pelatihan dalam bentuk program pemberdayaan sebagai upaya mengurangi dampak psikologis tindak kekerasan dan agar mampu meningkatkan daya pulih serta menjadikan korban tindak kekerasan lebih berdaya.

4. Pemerintah daerah beserta dinas/instansi terkait perlu membangun serta memperluas jaringan (networking) dengan LSM, Perguruan Tinggi, tokoh agama sebagai upaya untuk pencegahan, penanganan, dan penguatan korban tindak kekerasan.

\section{DAFTAR PUSTAKA}

Agusni S, Solekhah H (penyunting). 2010. Perempuan ke Gender dalam Pembangunan: Transformasi WID ke GAD. Secercah Cahaya Menuju Kesejahteraaan Perempuan (sebuah kajian). Kementrian Sosial RI Direktorat Jenderal Pemberdayaan Sosial Direktorat Pemberdayan Keluarga. 399 hal

[BPS] Badan Pusat Statistik. 2010. Perkembangan Beberapa Indikator Utama Sosial-Ekonomi Indonesia. [Internet]. [dikutip 01 Oktober 2011]. Dapat diunduh dari: http://www.bps.go.id/_booklet/Boklet_Agustus 2010.pdf

[BPS] Badan Pusat Statistik. 2011. Perkembangan Beberapa Indikator Utama Sosial-Ekonomi Indonesia. [Internet]. [dikutip 01 Oktober 2011]. Dapat diunduh dari: http://www.bps.go.id/booklet/Booklet_Agustus _2011.pdf

[BPS] Badan Pusat Statistik. [tidak ada tahun]. Human Development Index (HDI) by Province and National 1996-2010. [Internet]. [dikutip 17 Juli 2012]. Dapat diunduh dari: http://dds.bps.go.id/eng/tab_sub/view.php?tabe $\mathrm{l}=1 \&$ daftar $=1 \&$ id_subyek $=26 \&$ notab $=2$

Hubeis AVS. 2010. Pemberdayaan Perempuan dari Masa ke Masa. Bogor [ID]: IPB Press. 439 hal

[Inpres] Instruksi Presiden Nomor 9 Tahun 2000 Tentang Pengarusutamaan Gender (PUG) Dalam Pembangunan Nasional. [tidak ada tahun]. [Internet]. [dikutip 09 Maret 2012]. Dapat diunduh
http://suyatno.blog.undip.ac.id/files/2010/09/In pres-No.-9-tahun-2000-tentang-PUG.pdf

Kartika T, Solekhah H (penyunting). 2010. Indikator Kesejahteraan Perempuan. Secercah Cahaya Menuju Kesejahteraaan Perempuan (sebuah kajian). Kementrian Sosial RI Direktorat Jenderal Pemberdayaan Sosial Direktorat Pemberdayan Keluarga. 399 hal

Koentjaraningrat. 1994. Metode-Metode Penelitian Masyarakat. Ed 3. Jakarta [ID]: Gramedia Pustaka Utama

Komnas Perempuan. 2011. Teror dan Kekerasan terhadap Perempuan: Hilangnya Kendali Negara Catatan KTP Tahun 2010. [Internet]. [dikutip 17 Juli 2012]. Dapat diunduh dari:http:/www.komnasperempuan.or.id/wpcontent/uploads/2011/06/REVISI-CATAHU2011-PDF.pdf

Poerwandari EK. 2000. Kekerasan terhadap Perempuan: Tinjauan Psikologi Feministik. Luhulima AS, editor. Pemahaman Bentuk-Bentuk Tindak Kekerasan Terhadap Perempuan dan Alternatif Pemecahannya. Jakarta [ID]: P.T. Alumni

Saptari R. 1997. Perempuan Kerja dan Perubahan Sosial: Sebuah Pengantar Studi Perempuan. Jakarta [ID]: Pustaka Utama Grafiti. 505 hal.

Singarimbun, Masri dan Sofian Effendi (ed). 2008. Metode Penelitian Survai. Jakarta [ID]: Lembaga Penelitian, Pendidikan, dan Penerangan Ekonomi dan Sosial (LP3ES).

Sunarto. 2009. Televisi Kekerasan dan Perempuan. Bogor [ID]: Grafika Mardi Yuana. 240 hal

Widanti A. 2005. Hukum Berkeadilan Gender. Jakarta [ID]: Penerbit Buku Kompas.288 hal 